\title{
A coupled geothermal model of the Alpokalja area, Hungary-Austria
}

\author{
Attila Kovács ${ }^{1 * *}$, Ágnes Rotár Szalkai ${ }^{1}$, Zsolt Kercsmár ${ }^{1}$, Tibor Cserny ${ }^{2}$ \\ ${ }^{1}$ Geological and Geophysical Institute of Hungary, Budapest, Hungary \\ ${ }^{2}$ University of West Hungary, Institute of Environmental and Earth Sciences, Sopron, Hungary
}

Received: January 28, 2015; accepted: January 28, 2015

\begin{abstract}
A coupled groundwater flow and heat transport model was developed for a trans-boundary geothermal reservoir located in the Alpokalja area. The study area lies in the western part of the Pannonian Basin, at the border between Hungary and Austria. The study area contains several famous geothermal water utilizations on both sides of the border, which has an impact on natural groundwater conditions. The aim of the modeling study was to evaluate the natural-state and production-state groundwater conditions, and to make predictions on cross-boundary interferences. A three-dimensional finite element-type coupled geothermal model was constructed to provide a coherent quantitative representation of geothermal flow systems. The model described the hydraulic behavior of the flow system, the interaction between different reservoirs, and geothermal conditions.
\end{abstract}

Keywords: geothermal energy, groundwater flow, heat transport, trans-boundary reservoirs, modeling

\section{Introduction}

The study area is situated in the trans-boundary zone between Austria and Hungary. The area extends across the Oberpullendorf Basin in the west, gradually descending eastward into the southern part of the Little Hungarian Plain (Kisalföld). The Oberpullendorf Basin is surrounded by the Sopron-Ödenburger Range, the Rosalia Range, the Bucklige Welt and the Köszeg-Rechnitz Range. The elevation of the surrounding mountains varies between 400 and $900 \mathrm{~m}$ and the lowest point of the study area is $119 \mathrm{~m}$ asl. The geographic settings are shown in Fig. 1.

\footnotetext{
* Corresponding author: Stefánia út 14, H-1143 Budapest, Hungary.

E-mail: kovacs.attila@mfgi.hu
} 


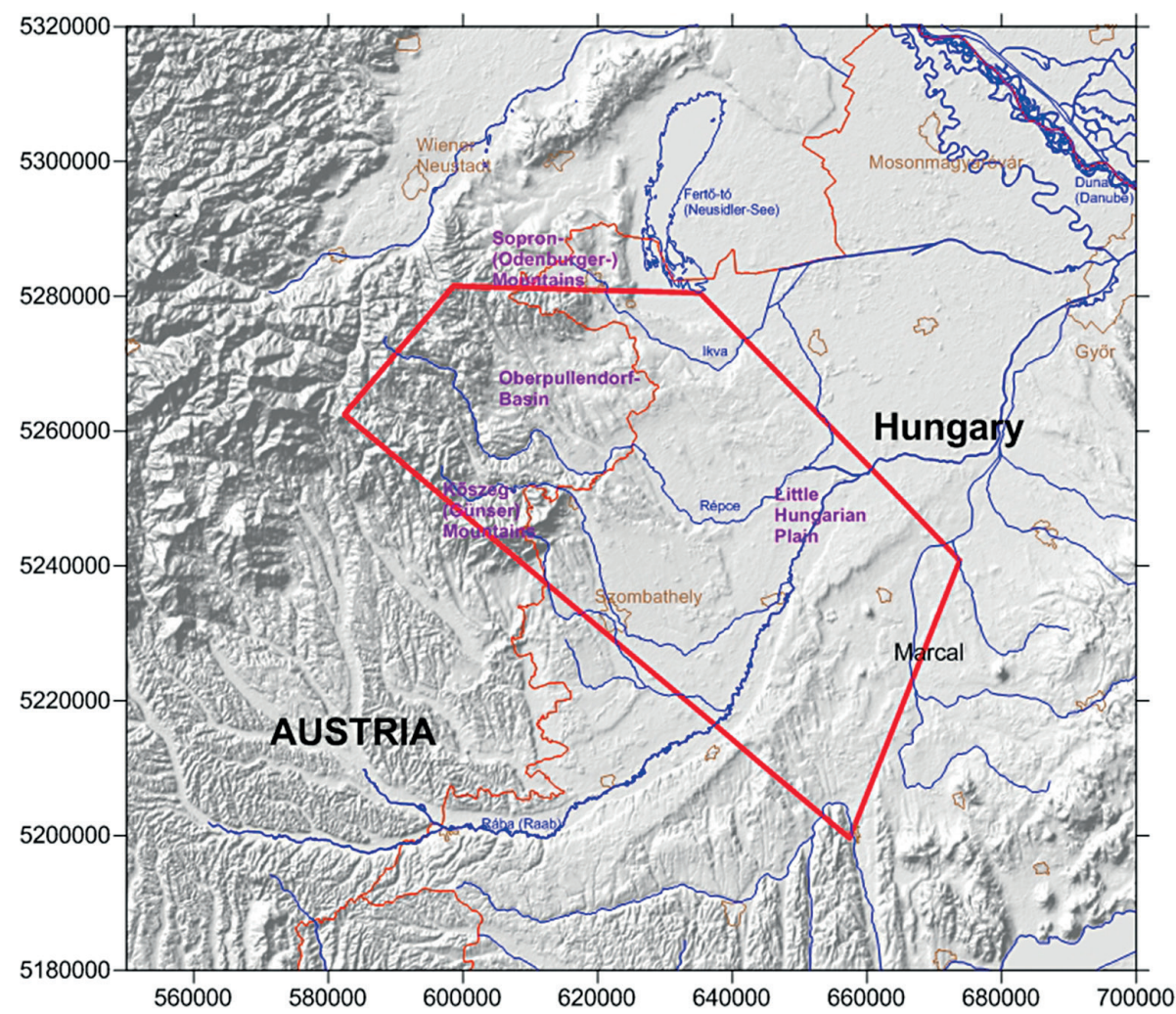

Fig. 1

Geographical settings of the pilot area and the model region

Balneology and balneologic tourism are important parts of the regional economy. Several famous spas are operated in the region within a relatively short distance from each other on both sides of the border, such as Sárvár, Bük and Lutzmannsburg. In addition to the well-known spas, there are several smaller users, like hotels and baths, and further demand for new balneologic utilizations exist.

Within the framework of the TRASENERGY (TE) project three different thermal water reservoirs were outlined in the investigation area (Rotár-Szalkai 2012). The present study aims at clarifying the hydraulic connections among the identified reservoirs and the recharge and thermal conditions of the investigation area.

A three-dimensional finite element-type coupled geothermal model was constructed to provide a coherent quantitative representation of geothermal flow systems. The model described the hydraulic behavior of the flow system, the interaction between different reservoirs, and the geothermal conditions. The model results provide information on trans-boundary depressurization of the geothermal 
reservoirs. Scenario modeling was undertaken to predict the effects of groundwater extractions. The applied model can be used as a tool for sustainable thermal water management. Based on model results a geothermal resource assessment was carried out.

\section{Geologic, hydrogeologic and geothermal conditions}

The Lutzmannsburg-Zsira area has no natural geologic borders. The basement consists mainly of metamorphosed crystalline rocks of the Austroalpine (Semmering-Wechsel System) and the Penninic (Rechnitz Window) units outcropping in the western margin of the area. These units form different nappe systems thrusted upon each other (Fig. 2). The tectonic movements and the deep structural position resulted in the metamorphosis of the basement rocks. In addition to the metamorphic crystalline rocks the Devonian Bük Dolomite Formation is an important aquifer unit of the basement that hosts thermal water resources in the area. The crystalline basement

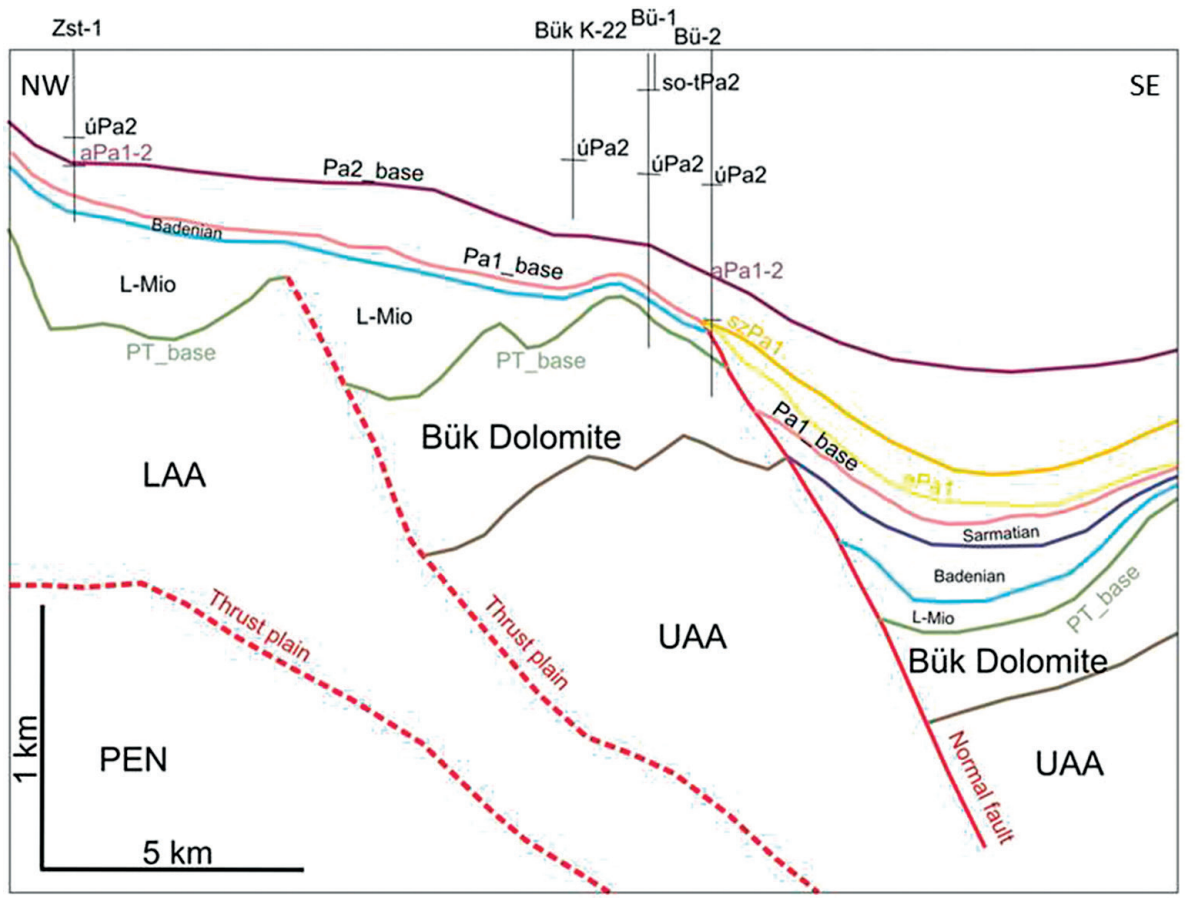

Fig. 2

Main structural elements of the eastern part of the Zsira-Lutzmannsburg pilot area (Hungary). Abbreviations: UAA: Upper Austroalpine Unit, LAA: Lower Austroalpine Unit, PEN: Penninic Unit, L-Mio: Lower Miocene formations, Pa1: Lower Pannonian formations, Pa2: Upper Pannonian formations 
formations are represented by fractured aquifers, usually with low permeability. Nevertheless, in structural zones and the upper weathered zone their permeability can be higher, and they can act as reservoirs. Due to their deep basinal position little information is available about their characteristics.

The basement is covered with Neogene sediments which were deposited in morphological depressions on the tectonically-preformed surface of the crystalline basement units. The Miocene-Pannonian porous sediment series increases in thickness toward the ESE. The maximum thickness is 2,000 $\mathrm{m}$ in the eastern part of the region.

The early Miocene (Eggenburgian and Ottnangian) formations are characterized by continental sedimentation made up of limnic, marsh or deep paludal successions with lignite. These sediments are overlain by the Karpatian-Lower Badenian succession of fluvial, subordinately brackish water gravel, conglomerate, sand and marl. The lower part of the Lower Badenian is absent over the entire area due to Early Badenian tectonic movements and erosion. In the Badenian a variety of sedimentary environments existed. Nearshore facies are characterized by sand-sandstone, locally with "Leithakalk" deposition. Offshore deep-basin (shallow bathyal) facies are represented by fine siliciclastic sediments: sandy silt, silty clay marl with sandstone intercalations and sandy-silty clay marl. The nearshore sediments usually form aquifers and offshore silt and marl form regional aquitard layers. At the margin of the basin the aquifer layers are in hydraulic connection with the surface, but inside the basin they form closed units without or with restricted hydraulic connections.

The Upper Miocene-Pannonian series were deposited in a delta environment. Sediments deposited in the delta slope environment are mostly comprised of clay and marl, and act as regional aquitards. The isolated permeable sand bodies derived from turbidites have no connections with other aquifer units. This formation physically separates the upper thermal waters from the lower geothermal systems.

The sedimentary succession deposited in delta front and delta plain environment is built up of altering layers of sand, silt and clay. The whole unit acts as one aquifer system.

The main recharge of thermal groundwater is from infiltrating precipitation in the high elevated mountain region, mainly situated in Austria. Part of the infiltrated precipitation returns to the surface after a short path forming local flow systems. The other part descends toward the deeper layers and enters the regional flow system. At depth, along the deeper flow paths, the groundwater warms up, and changes its chemical character due to water-rock interactions. In some places where the basement is connected to the porous formations of the Neogene basins, the groundwater of the basement aquifers exchange water with the porous units. At other locations the flow system of the basement is separated from the porous aquifer units. The direction of groundwater flow in the Miocene-Pannonian sediments is west to east. Groundwater partly flows toward the Marcal River, or turns to the NNE in the direction of the Hanság region. Under natural conditions several wetlands, especially Hanság, played an important role in groundwater discharge. Recently there are only small patches of wetlands left; the groundwater discharges into artificial drainage networks. 
The geothermal conditions can be characterized by available maximum temperature, which increases eastward along with basement depth. It begins to decrease at the southeastern margin of the area, where the basement rises again toward the outcropping Transdanubian Range. The highest temperature occurs in the Szombathely-Sárvár Zone, where the temperature of the basement varies between 80 and $110^{\circ} \mathrm{C}$. The deepest temperature measurements were undertaken in the crystalline basement at Egyházasrádóc (Rád-1) at a depth of 3,401.5 m, where the temperature reached $115.8^{\circ} \mathrm{C}$. The Rád-2 borehole showed $112^{\circ} \mathrm{C}$ at $2,950 \mathrm{~m}$ depth.

\section{Geothermal reservoirs}

Three different reservoirs have been identified in the pilot area:

- Upper Pannonian porous reservoir,

- Miocene porous reservoir with double porosity,

- Fractured basement carbonate reservoir (Bük Dolomite).

The Bük Dolomite aquifer comprises three separate blocks, at over 1,000 m depth. These blocks have different hydraulic connection with adjacent units, which results in varying hydrochemical characteristics. The block located in the Bük region has restricted recharge, with lower (4,000-14,000 mg/l) TDS concentration. The other two blocks near Sárvár form closed structures without any significant recharge, and have a high total dissolved content.

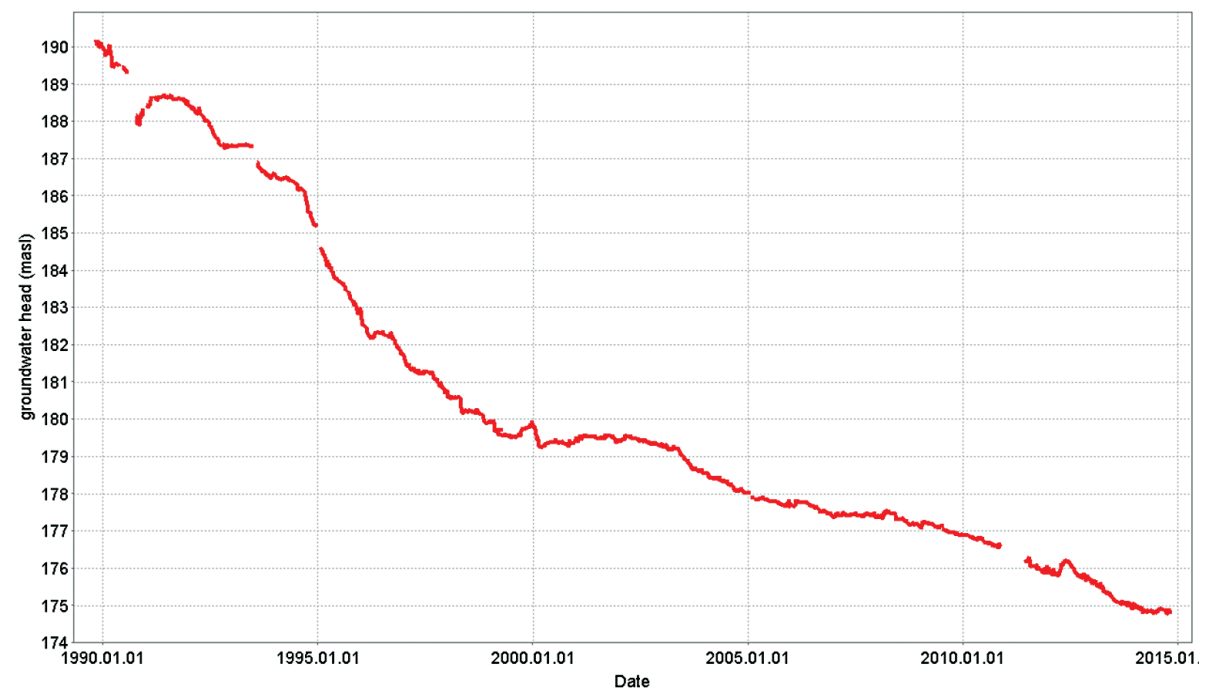

Fig. 3

Changes in groundwater heads in Zst-1 monitoring well 
One type of the Miocene reservoirs is comprised of conglomerate, sand and sandstone, deposited in a nearshore environment. These layers can be considered as porous thermal water reservoirs, with often direct hydraulic connection with the basement reservoirs. The Lutzmannsburg spa uses this Karpatian aquifer at the depths of 450 to $900 \mathrm{~m}$. Although the reservoir is supposed to have hydraulic connections and forms an open system, the hydraulic head shows a decreasing trend (Fig. 3).

The other type of Miocene thermal water aquifers are the widespread Badenian and Sarmatian shallow-marine clastic carbonates. The thickness of the Badenian units varies between 10 and $60 \mathrm{~m}$, while that of the Sarmatian ones varies between 50 and $120 \mathrm{~m}$. They are considered to be double porosity reservoirs. This type of reservoir is known only from hydrocarbon exploration wells.

The Late Miocene fluvio-deltaic sediments form a vast porous basin-fill complex. These sediments form important thermal water reservoirs. The Lower Pannonian layers consist mainly of clay or sandy clay; therefore they act as regional aquacultures. The Upper Pannonian sedimentary succession is built up of alternating sand and sandy clay layers. The entire sedimentary succession forms one hydrostratigraphic unit. This reservoir has good hydraulic connections both in the vertical and horizontal direction, and low total dissolved content (below 2,000 mg/l).
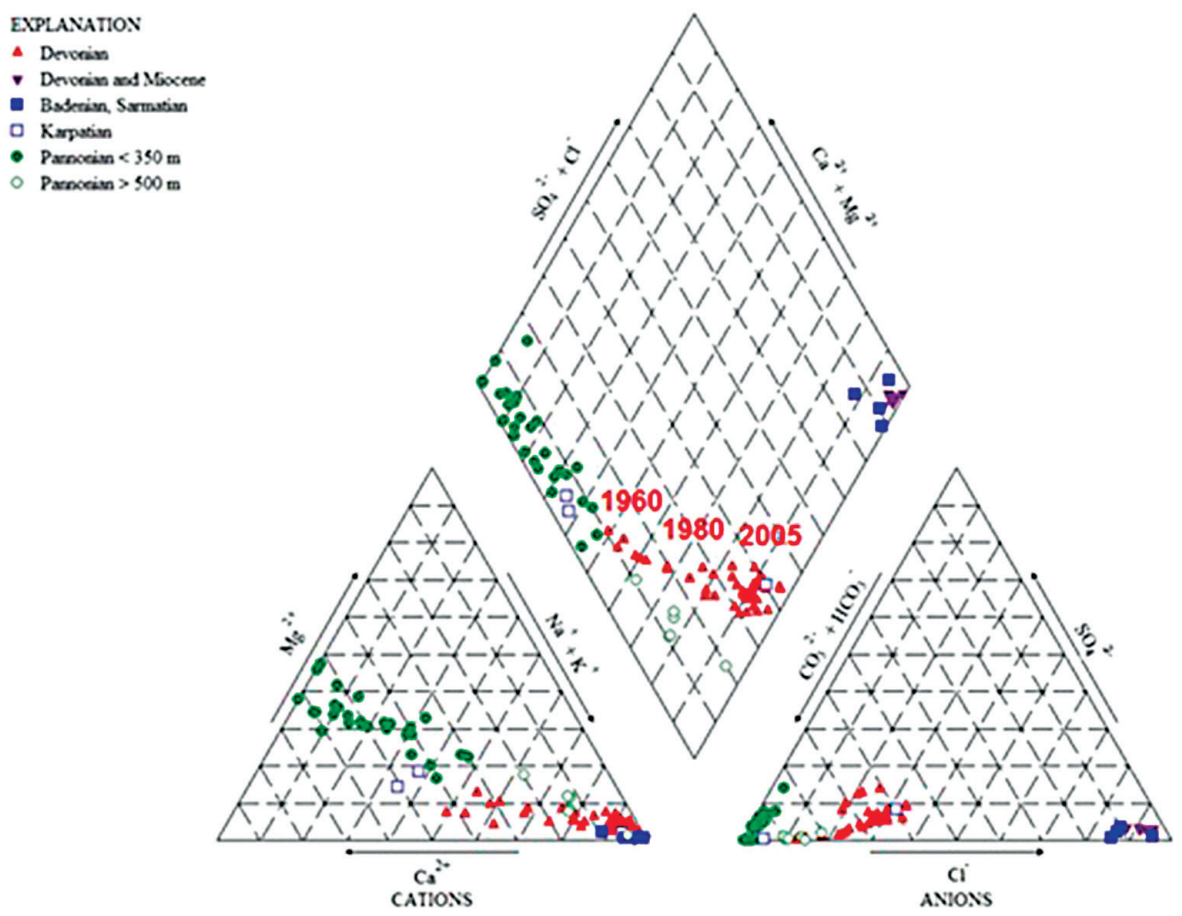

Fig. 4

Piper plot of main reservoir waters in the pilot area 
The analysis of water chemistry of the reservoirs indicates that Badenian reservoirs contain high-salinity waters which might alter the groundwater composition of the Bük Dolomite through mixing processes. The piper plot indicates the gradual change in water chemistry of the Bük Dolomite between 1960 and 2005 (Fig. 4). The plot clearly shows that the increasing salinity originates from mixing with waters of the Badenian reservoir.

\section{Coupled geothermal model}

To provide an overview of the large-scale hydrogeologic processes of geothermal systems and the connection between the main groundwater bodies, a supra-regional hydrogeologic model was developed within the framework of the TRANSENERGY project (Tóth et al. 2012; Rotár-Szalkai et al. 2013). The supra-regional model provided an overall characterization of the flow system, and was used for the definition of boundary conditions of the pilot models.

The aim of the regional-scale model was to understand and characterize the natural hydro-geothermal systems of the study area, to investigate the effects of existing geothermal water extractions, and to make predictions on different extraction scenarios. To achieve these goals, the modeling study included the following stages:

- Natural state modeling to understand the functioning of the natural geothermal system and to calibrate the numerical model (Kovács and Rotár-Szalkai 2013a);

- Simulation of current groundwater extractions to understand reservoir responses and hydraulic interference between extractions wells;

- Scenario modeling to investigate different extraction scenarios and to provide predictions on future reservoir conditions (Kovács and Rotár-Szalkai 2013b).

Model layering was based on conceptual hydrostratigraphy developed from the geologic model of the area (Maros et al. 2012). The following hydrostratigraphic units were distinguished:

- Crystalline basement formations;

- Devonian dolomite formation;

- Miocene formations;

- Lower Pannonian formations;

- Upper Pannonian formations;

- Quaternary formations.

Vertical model discretization was defined to provide sufficient accuracy and to maintain computational efficiency.

Boundary conditions were determined to support both the shallow (Upper Pannonian) and deep (pre-Neogene) flow systems. While natural surface water manifestations and regional water divides could be applied as flow boundaries in the case of the Upper Pannonian-Quaternary aquifer systems, boundary conditions were 
assigned from the supraregional-scale groundwater model to define boundaries of deeper systems.

Initial hydrogeologic parameters in this study were based on field measurements, literature data and model parameters applied in modeling studies targeting the study area (Csepregi et al. 2006; Tóth et al. 2012). Due to the limited information on site-specific field parameters, homogeneous parameter distributions were applied for each hydrostratigraphic unit (Table 1).

Table 1

Optimised hydraulic conductivities

\begin{tabular}{lll}
\hline Unit & Kxy $(\mathrm{m} / \mathrm{s})$ & $\mathrm{Kz}(\mathrm{m} / \mathrm{s})$ \\
\hline Quaternary & $1.1 \mathrm{e}-3$ & $1.1 \mathrm{e}-8$ \\
\hline Late Pannonian & $1.5 \mathrm{e}-6$ & $1.1 \mathrm{e}-8$ \\
\hline Early Pannonian & $1.1 \mathrm{e}-8$ & $1.1 \mathrm{e}-9$ \\
\hline Sarmatian & $5.0 \mathrm{e}-8$ & $1.0 \mathrm{e}-9$ \\
\hline Badenian & $1.0 \mathrm{e}-8$ & $1.0 \mathrm{e}-9$ \\
\hline Miocene & $8.0 \mathrm{e}-7$ & $1.0 \mathrm{e}-7$ \\
\hline Devonian & $8.0 \mathrm{e}-7$ & $1.0 \mathrm{e}-7$ \\
\hline Basement upper & $1.7 \mathrm{e}-8$ & $1.6 \mathrm{e}-9$ \\
\hline Basement lower & $4.7 \mathrm{e}-10$ & $8.8 \mathrm{e}-10$ \\
\hline
\end{tabular}

The geothermal model of the study area was based on the calibrated hydraulic model. The heat transport component was coupled with the hydraulic model to simulate convective and conductive heat transfer. The following heat boundary conditions were applied:

- Constant temperature boundary condition of $\mathrm{t}=10^{\circ} \mathrm{C}$ was applied at the top slice. This boundary represents an average atmospheric temperature at the ground surface.

- A heat flux boundary condition was applied at the model base (-5,000 mASL). The spatially varying heat flux distribution was obtained from the supra-regional conductive model of Goetzl et al. (2012). The applied values vary between $55-90 \mathrm{~mW} / \mathrm{m}^{2}$.

- A constant temperature boundary condition of $\mathrm{t}=10-30^{\circ} \mathrm{C}$ was applied on slices 6-11 along the western model boundary. This boundary condition represents the temperature of groundwater inflow from the west.

Uniform parameter distributions were used in the main hydrostratigraphic units. The same parameter zones were applied for thermal properties as for hydraulic properties. Initial parameter values were obtained from laboratory measurements under- 
taken within the framework of the TE project. Additional data was obtained from Tóth et al. (2012). The thermal properties applied in the model are listed in Table 2.

Table 2

Thermal properties

\begin{tabular}{llllll}
\hline Unit & Model layers & Porosity & $\begin{array}{l}\text { Thermal } \\
\text { conductivity }(\mathrm{W} / \mathrm{mK})\end{array}$ & $\begin{array}{l}\text { Longitudinal } \\
\text { dispersivity }(\mathrm{m})\end{array}$ & $\begin{array}{l}\text { Transverse } \\
\text { dispersivity }(\mathrm{m})\end{array}$ \\
\hline Quaternary & 1 & 0.3 & 2 & 5 & 0.5 \\
\hline Late Pannonian & $2-4$ & 0.2 & 2 & 5 & 0.5 \\
\hline Early Pannonian & 5 & 0.2 & 3 & 5 & 0.5 \\
\hline Sarmatian & 6 & 0.2 & 3 & 5 & 0.5 \\
\hline Badenian & 7 & 0.1 & 3 & 5 & 0.5 \\
\hline Miocene & 8 & 0.1 & 3 & 5 & 0.5 \\
\hline Devonian & 9 & 0.1 & 3 & 5 & 0.5 \\
\hline Basement upper & 10 & 0.05 & 3 & 5 & 0.5 \\
\hline Basement lower & $11-12$ & 0.05 & 3 & 5 & 0.5 \\
\hline
\end{tabular}

First a steady-state model was developed. The model describes the system in natural condition (before thermal water withdrawals began), and provides the basis for the scenario models. The steady-state model expresses the temperature distribution in $3 \mathrm{D}$ considering the effects of groundwater flow. Both the hydraulic and thermal models were based on a detailed geologic model, which determined the geometry and parameter distribution of the model.

In order to separate the hydraulic influence of different water extractions and to determine the sources of depressurization observed in the Zsira Zst-1 well, a production state model was developed. By »switching off « user groups in certain areas, different scenarios could be investigated and the hydraulic impact of abstraction wells could be evaluated. The simulated scenarios included the following:

1. No groundwater extractions at Bük;

2. No groundwater extractions at Lutzmannsburg;

3. No groundwater extractions at Bük or Lutzmannsburg;

4. No groundwater extractions in the Upper Pannonian aquifer;

5. No groundwater extractions in the Hungarian part of the pilot area;

6. No groundwater extractions in the Austrian part of the pilot area;

The model focused on the Lutzmannsburg-Zsira trans-boundary local system, which comprises the following components:

- Two extraction wells at Bük: Bük K-4 and Bük K-10 abstract groundwater from the Devonian Bük Dolomite at a total rate of $1500 \mathrm{~m}^{3} /$ day. Production of ther- 
mal groundwater began in 1962 at a rate of $200 \mathrm{~m}^{3} /$ day and gradually increased over the following years to the current extraction rate. The temperature of the outflowing water is $58{ }^{\circ} \mathrm{C}$.

- Two extraction boreholes at Lutzmannsburg: Thermal-1 and Thermal-2 started operation in 1994 at an abstraction rate of $430 \mathrm{~m}^{3} /$ day. These wells are screened within the Karpatian sediments, and are operated alternately.

- An observation borehole at Zsira: Zst-1 is screened within the Karpatian sediments, and is located between the Zsira and the Lutzmannsburg extraction wells, thus providing information on the combined effects of these productions.

The stratigraphic setup of the local system is shown in a cross-section in Fig. 5. The figure indicates that the Devonian dolomite block is partially overlain by Karpatian sediments in the west, and Badenian sediments in the east. This is the consequence of the pinching out of Karpatian sediments above the dolomite body.

Since the beginning of groundwater extraction at the above location, changes in groundwater conditions were observed. A gradual increase of the concentration of main water components including $\mathrm{Na}, \mathrm{K}, \mathrm{HCO}_{3}, \mathrm{Cl}$ and $\mathrm{SO}_{4}$ was observed in Bük K-4 and K-10 and a gradual pressure drop up to $15 \mathrm{~m}$ was observed in Zsira Zst-1.

The goal of the modeling study with respect to the Lutzmannsburg-Zsira local trans-boundary system was to answer the following questions:

- What is the source of saline groundwater observed in the Bük boreholes?

- Which extractions cause the depressurization observed in the Zsira Zst-1 monitoring borehole?

In order to investigate the thermal effects of reinjection of thermal water, a geothermal doublet has been simulated. The doublet model included the simulation of an
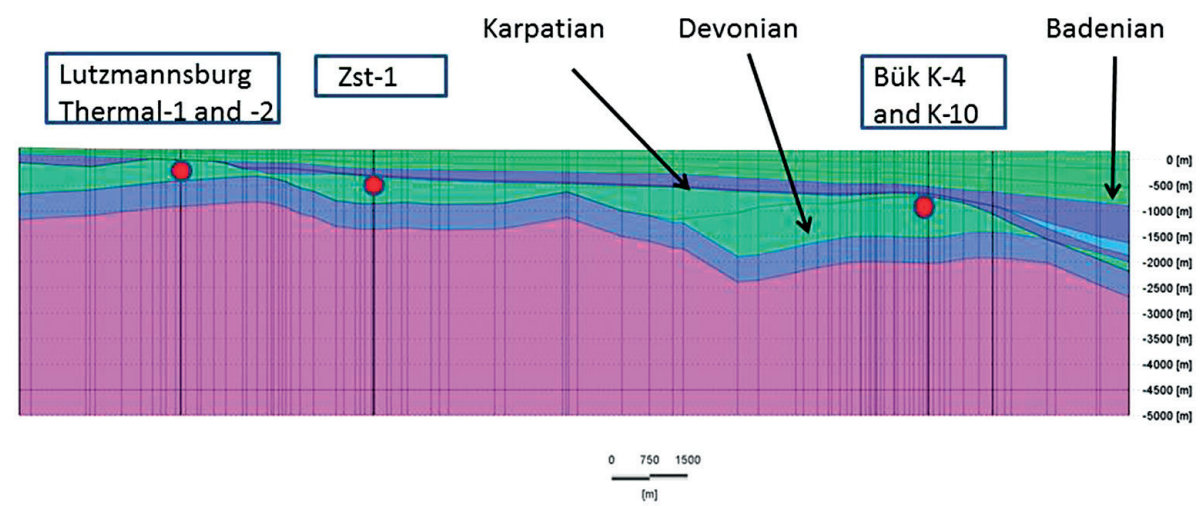

Fig. 5

Local hydrostratigraphy of the Lutzmannsburg-Zsira local system (NW-SE cross-section) 
extraction and a reinjection borehole in the eastern Devonian dolomite block. This reservoir is similar to the dolomite reservoir exploited by the Bük extraction boreholes, but is hydraulically independent and thus not affected by artificial activities. Similarly to the Bük extraction wells, a $1,500 \mathrm{~m}^{3} /$ day abstraction rate has been applied. According to the applied scenario, the same amount is reinjected in a borehole located approximately $500 \mathrm{~m}$ apart, using a conservative approach assuming infinite operation time.

\section{Results}

The coupled groundwater flow and heat transport model provided three-dimensional information of hydraulic head distribution (Fig. 6), groundwater fluxes and temperature distribution under natural conditions.

The simulated groundwater head distribution and calculated flux distribution indicate that the dominant flow direction within the model domain is from west toward the northeast, east and southeast. The flow field follows a semi-radial pattern. The main inflow area is along the western model boundary in the territory of Austria, where the regional flow system feeds the modeled domain. Outflow occurs along the southeastern (Marcal Valley) and northeastern model boundaries. The Marcal Valley represents the regional discharge area, while the northeastern side of the model is a

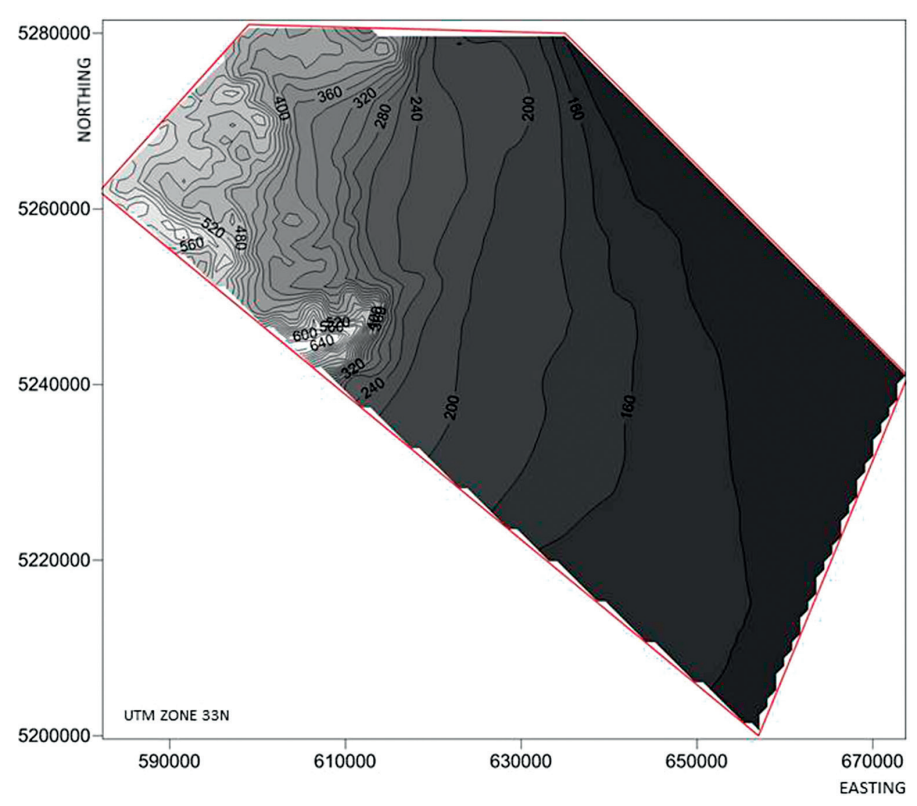

Fig. 6

Simulated hydraulic head distribution in the Sarmatian layers (slice 8) without extraction 


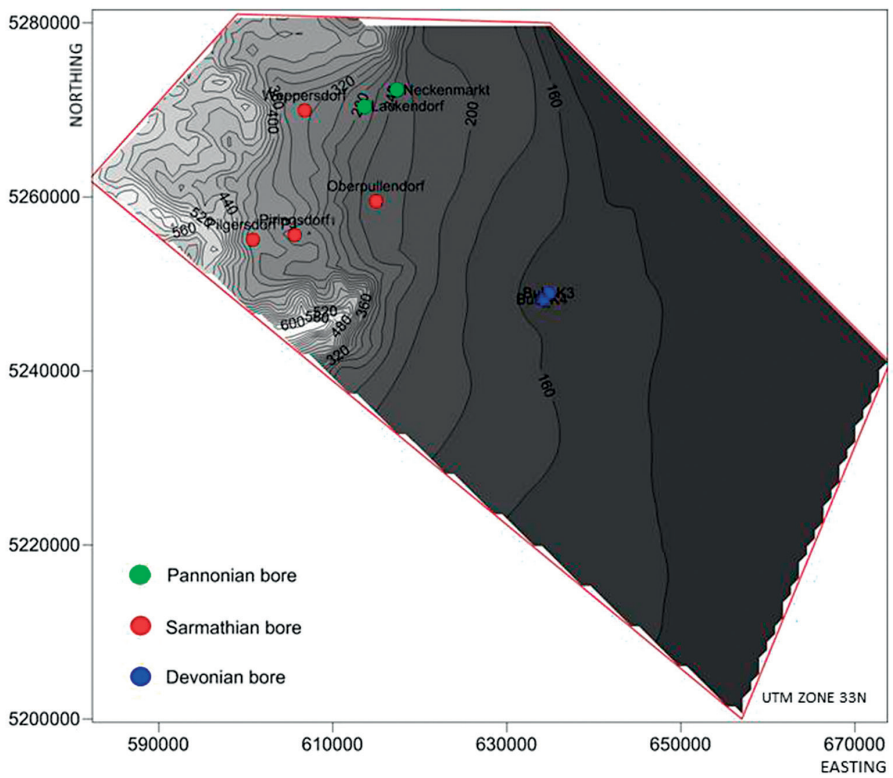

Fig. 7

Simulated head distribution in the Sarmatian reservoir - production state

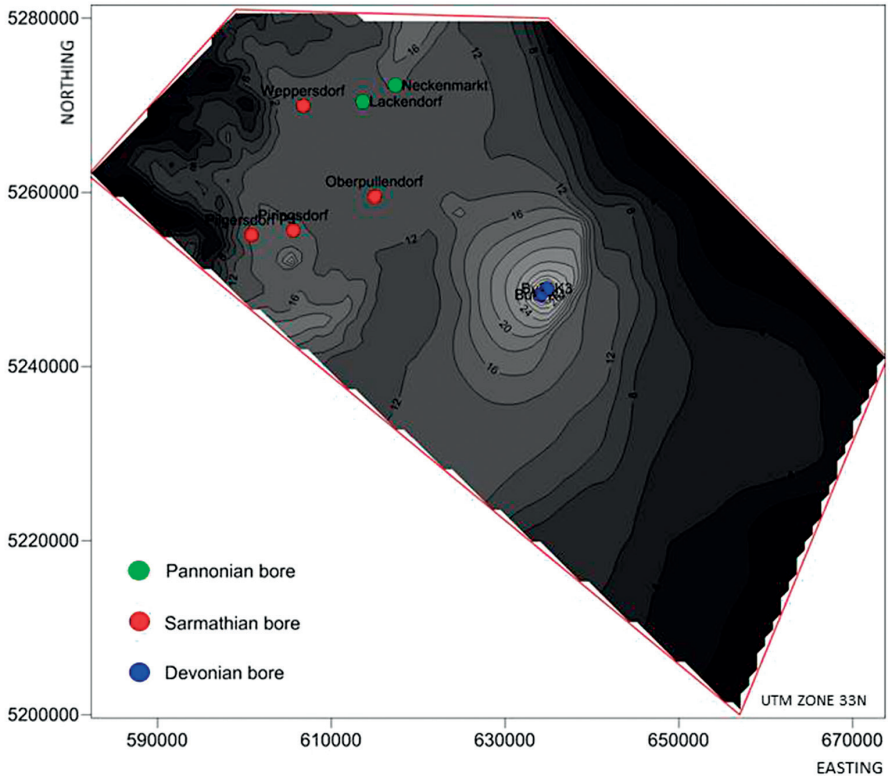

Fig. 8

Simulated drawdown, Sarmatian reservoir 
cross-flow area. Surface infiltration represents approximately $97 \%$ of groundwater recharge, while the rest arrives as groundwater inflow from the west.

The coupling of the hydraulic and heat transport models made it possible to calculate a 3D temperature distribution over the study area. The simulated temperature distribution indicates little vertical variation of temperature within the Upper Pannonian sediments, and gradually increasing temperatures within older sediments and the fractured basement.

The simulation of the current production scenario included all known groundwater extractions within the model area. The majority of groundwater extractions (53\%) occur from the Upper Pannonian aquifer. Nine percent of total extractions occur from the Quaternary aquifer, while 3.5\% is abstracted from the Sarmatian reservoir. Devonian boreholes extract $1.5 \%$ of the total rates. Model simulations indicate that regional groundwater table drawdown varies between 1 and $15 \mathrm{~m}$ in response to groundwater extraction. The largest drawdowns occur in the western side of the model domain. The depressurization of the pre-Neogene aquifers generally varies between 2 and $12 \mathrm{~m}$. The largest pressure drop exists around the Bük extraction boreholes (Figs 7 and 8).

As part of the investigation of the source of saline water in the LutzmannsburgZsira local system, flow directions were analyzed in the vicinity of the Bük extraction boreholes. Piezometric plots along a cross-section including the Lutzmannsburg, Zsira and Bük wells are provided in Fig. 9. The flow vectors in the natural state and under current production conditions are indicated in Fig. 10.

The piezometric plots indicate significant depressurization both at the location of the Bük and the Lutzmannsburg boreholes. The flow vectors indicate the reversal

a)
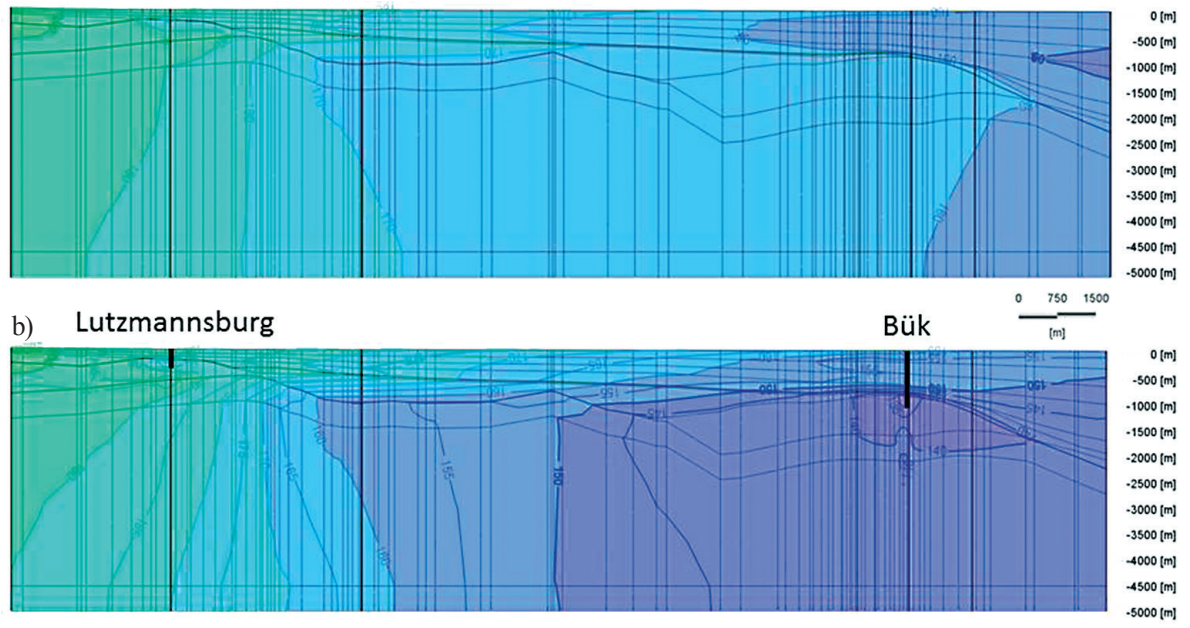

Fig. 9

Piezometric cross-sections (NW-SE) across the Lutzmannsburg, Zsira and Bük bores [a) natural state, b) production state] 
a)

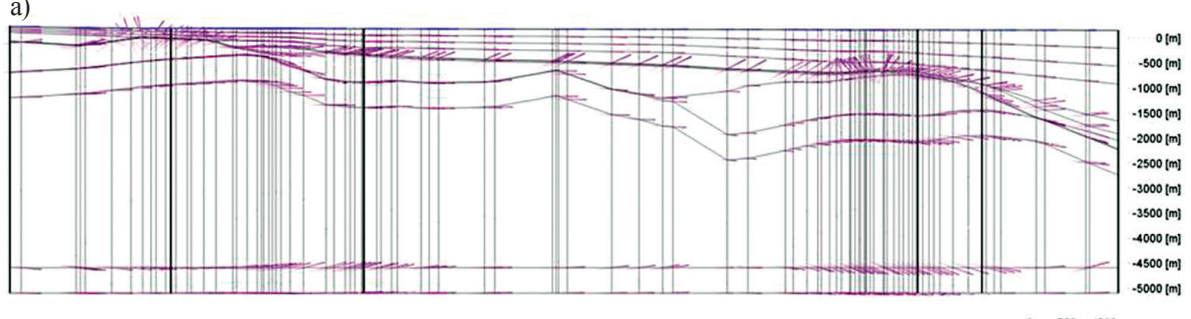

b) Lutzmannsburg $\underbrace{750 \quad 1500}_{[\mathrm{m} !}$

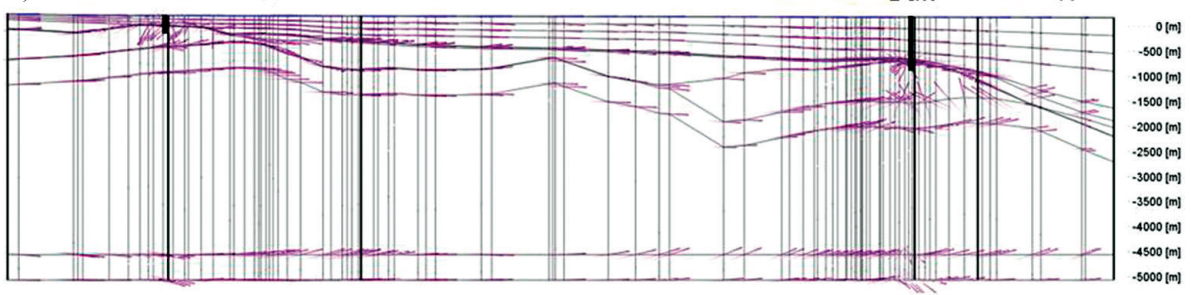

Fig. 10

Flow vectors along NW-SE cross-sections across the Lutzmannsburg, Zsira and Bük boreholes [a) natural state, b) production state]

of natural flow directions at these locations. While the natural recharge of the Bük Dolomite is through the overlying Karpatian sediments from the west, the depressurization causes the reversal of natural flow. As a consequence, groundwater leaks into the Devonian reservoir not only from the Karpatian but also from the overlying Badenian sediment located in the west, and from the low-permeability basement rocks underlying the Bük Dolomite. The production-induced leakage directions are indicated in Fig. 11.

In order to separate the hydraulic in-

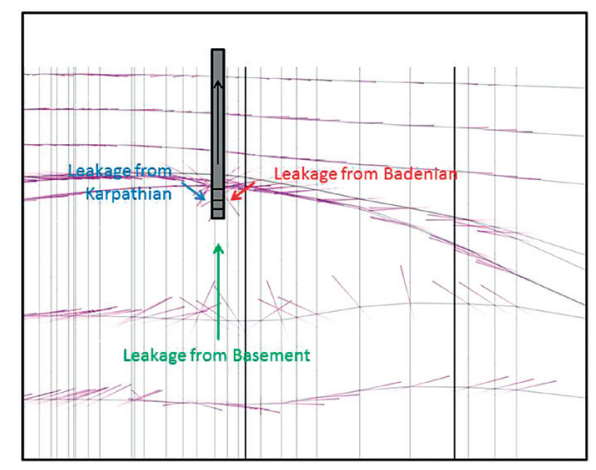

Fig. 11

Groundwater leakage in response to production from the Bük dolomite block fluence of different water extractions and to determine the sources of depressurization observed in the Zsira Zst-1 well, the production-state model was applied. By »switching off « user groups, certain areas and different scenarios could be investigated, and the hydraulic impact of abstraction wells could be evaluated. Table 3 shows the simulated depressions applying the different scenarios.

To be able to investigate the potential consequences of the future stress on the geothermal and groundwater systems of the pilot area, a twofold increase in production rates was simulated. This included the increase of existing production (no additional 
production boreholes were introduced) and the simulation of equilibrium potentials. Simulation results predict a significant increase in steady-state water table drawdown up to $16 \mathrm{~m}$ in the border zone of the pilot area. While simulated drawdown at current production was around $10-12 \mathrm{~m}$, the predicted drawdown due to increased abstraction in this area is as much as $26-28 \mathrm{~m}$.

Table 3

Simulated depressurisations

\begin{tabular}{llcccccc}
\hline \multirow{2}{*}{ Bore } & \multicolumn{7}{c}{ Simulated depressurisation $(\mathrm{m})$} \\
\cline { 2 - 8 } & $\begin{array}{l}\text { Current } \\
\text { production }\end{array}$ & 1 & 2 & 3 & 4 & 5 & 6 \\
\cline { 2 - 8 } & 15.3 & 10.6 & 14.1 & 9.6 & 9.7 & 5.1 & 11.2 \\
\hline Zsira-1 & 32.3 & 30.7 & 11.4 & 10.1 & 21.5 & 25.7 & 27.3 \\
\hline Lutzmsb Th-1 & 32.9 & 9.4 & 59.0 & 9.1 & 51.5 & 3.1 & 56.8 \\
\hline Bük K-4 & 59.9 & 9.3 & 49.3 & 8.9 & 41.8 & 3.0 & 47.1 \\
\hline Bük K-10 & 49.8 & & & & & &
\end{tabular}

According to the well doublet scenario the reinjection borehole has a thermal influence within a circle of $4 \mathrm{~km}$ radius around the well. The cooling effect does not extend far beyond the boundaries of the dolomite block. Using a transient simulation, the thermal influence did not extend more than $500 \mathrm{~m}$ around the reinjection well within 20 years of simulation time. The simulated drawdown plots indicate that the extraction borehole has a steady-state depressurization of up to $60 \mathrm{~m}$ without reinjection. If reinjection is applied, the maximum depressurization rate around the extraction well dropped to $13 \mathrm{~m}$. At the same time, a pressure increase of $7 \mathrm{~m}$ developed around the reinjection borehole.

\section{Conclusions}

Based on a detailed 3D geologic model, a coupled groundwater flow and heat transport model was developed. The natural-state model provided three-dimensional information on hydraulic head distribution, groundwater fluxes and temperature distribution. The simulated groundwater head distribution and calculated flux distribution indicated that the dominant flow direction is toward the east following a semi-radial pattern. The groundwater is recharged mainly via surface infiltration. The Marcal Valley and the Répce valley represent the regional discharge area, while the northeastern side of the model is a cross-flow area.

With respect to the Lutzmannsburg-Zsira local system, the model scenarios indicate that both the Bük and Lutzmannsburg extractions contribute to the drawdown 
observed in the Zsira (Zst-1) monitoring borehole. The Upper Pannonian extractions also contribute to the depressurization observed in Zst-1. The contribution of the Upper Pannonian and Quaternary extractions is comparable to that of the Bük and Lutzmannsburg abstractions. Both abstraction groups contribute equally to the depressurization along the border zone. The Sarmatian production boreholes also contribute to the depressurization in the border zone. Both Austrian and Hungarian extractions take part in the depressurization demonstrated in Zst-1.

The simulation of a twofold increase in existing extraction rates indicates a significant increase in water table drawdown of up to $16 \mathrm{~m}$ in the border zone of the pilot area. Similarly, the current depressurization of the Sarmatian reservoir was predicted to increase by $18 \mathrm{~m}$ in response to increased production rates. Both Austrian and Hungarian extractions contribute to the depressurization in Zst-1. Predictive model results suggest that the increase of extraction rates would put a significant stress on the thermal system.

Based on the simulation of a theoretical well doublet, it can be stated that reinjection of the extracted fluids significantly decreases the hydraulic impacts of thermal water production. The cooling effect of cold water reinjection had little influence on the temperature distribution within 20 years of simulation time, and has only a local impact on reservoir temperatures in the case of long-term utilization.

\section{References}

Csepregi, A., Gy. Ágotai, G. Izápy 2006: Wellhead protection zone delineation, Bük thermal spa area. Manuscript, HYDROSYS Ltd.

Goetzl, G., F. Zekiri, L. Lenkey, D. Rajver, J. Svasta 2012: Summary report: Geothermal models at supra-regional scale for Transenergy project. - Project report, http://transenergy-eu.geologie.ac.at/.

Kovács, A., Á. Rotár-Szalkai 2013a: Report on the Zsira-Lutzmannsburg pilot area model. - Project report, http://transenergy-eu.geologie.ac.at/.

Kovács, A., Á. Rotár-Szalkai 2013b: Report on the Zsira-Lutzmannsburg pilot area scenario modelling study. - Project report, http://transenergy-eu.geologie.ac.at/.

Maros, Gy., R. Barczikay-Szeiler, L. Fodor, L. Gyalog, E. Jocha-Edelényi, Zs. Kercsmár, Á. Magyari, V. Maigut, L. Orosz, K. Palotás, I. Selmeczi, A. Uhrin, Zs. Vikor, B. Atzenhofer, R. Berka, M. Bottig, A. Brüstle, C. Hörfarter, G. Schubert, J. Weilbold, I. Baráth, K. Fordinál, B. Kronome, J. Maglay, A. Nagy, B. Jelen, A. Lapanje, H. Rifelj, I. Rižnar, M. Trajanova 2012: Summary report of Geological models of the Transenergy project. - Project report, http://transenergy-eu.geologie.ac.at/.

Rotár-Szalkai, 2012: Evaluation of potential demonstration sites by outlining geothermal reservoirs above $50{ }^{\circ} \mathrm{C}$. - Project report, http://transenergy-eu.geologie.ac.at/.

Rotár-Szalkai, A., Gy. Tóth, Gy. Maros, L. Lenkey, G. Götzl, A. Lapanje, R. Černák 2013: Integrated geoscientific modelling of the Transenergy project area. - In: Geothermal Energy towards new horizon. European Geothermal Congress, Pisa, 3-7 June 2013, ISBN 978-2-8052-0226-1, extended abstract.

Tóth, Gy., Á. Rotár-Szalkai, T. Kerékgyártó, T. Szőcs, E. Gáspár, A. Lapanje, N. Rman, J. Svasta, R. Cernak, A. Remsik, G. Schubert, R. Berka, G. Goetzl 2012: Summary report of the supra-regional hydrogeological model. - Project report, http://transenergy-eu.geologie.ac.at/. 